\title{
Titiluri Tegger: \\ Aktualisasi Tradisi, Refleksi Jati Diri dan Strategi Konservasi
}

\author{
Dina Fitria Hasanah ${ }^{1}$ \& Sony Sukmawan ${ }^{2}$ \\ Program Studi Pendidikan Bahasa dan Sastra Indonesia \\ FIB Universitas Brawijaya, Malang, Indonesia \\ 1 dina.fh@student.ub.ac.id \& ${ }^{2}$ sony_sukmawan@ub.ac.id
}

\begin{abstract}
The Tengger community coexists with cultural diversity. Titiluri presents to behold in maintaining cultural wealth. Focusing on what the ancestors have done, titiluri is a bridge in reducing the goodness that has existed since time immemorial. This study used a qualitative approach to the design of ethnography to describe titiluri role in maintaining society's culture Tengger. Through ethnographic design, a holistic description of folkloristic expression is embodied in expressions, speeches, symbolic behaviors that contain the philosophy of titiluri. Data were collected using observation and interviews. As a result, Titiluri is present in every aspect of the Tengger community. As a form of actualization of tradition, the titluri is shown to take place various traditional ceremonies until now as has been done by the ancestors. Besides, titiluri is present in the form of the Tengger community's identity, with inherent selfcharacter, occupation, and dress characteristics. Titluri has the role of conserving the Tengger culture and becomes a principle in maintaining the nobility built by the ancestors so that it can save from the strong exposure of modernization.
\end{abstract}

Keywords: titiluri, tradition, tengger ancestors, cultural conservation.

\section{PENDAHULUAN}

Wong Tengger merupakan kelompok masyarakat yang bermukim di kawasan Bromo dengan alam yang subur dan budaya yang melimpah.Untuk menjaga keseimbangan dalam mempertahankan kekayaan tersebut, masyarakat Tengger menggerakkan titiluri sebagai pilar penguatnya.Titiluri merupakan suatu kebiasaan masyarakat Tengger yang didapatkan dari ajaran turun-temurun nenek moyang.Sesuatu yang dititiluri berupa tradisi, kegiatan keseharian, kegiatan kemasyarakatan, dan pekerjaan. Pendek kata, adat istiadatwarisan leleuhur di-titiluri secara konsistenoleh masyarakat pemangku adat Tengger. Masyarakat Tengger me-nitiluri segala hal baik dan luhur yang diturun temurunkan oleh leluhur.Mereka beranggapan bahwa leluhur telah memberi amanat sehingga wajib diikuti oleh generasi selanjutnya.Warsaa (2019) mengungkapkan bahwa masyarakat Jawa memahami titilurisebagai mengikuti jejak para leluhur atau meneruskan agama, kepercayaan, dan adat istiadat nenek moyang 
secara turun-menurun.Hal ini berkenaan dengan keyakinan yang mereka anut secara turun-temurun yang terus dilanjutkan guna menanamkan nilai-nilai luhur yang ada.

Titiluri diwujudkan oleh masyarakat Tengger sebagai dasar dalam melakukan acara sakral yang berkenaan antara manusia dengan Sang Pencipta.Melakukan upacara, memakai atribut khas Tengger, serta menjalankan kewajiban-kewajiban termasuk dalam titiluri. Titiluri berasal dari bahasa Tengger, yaitu titi dan luri.Titimemiliki arti meniti atau niti' dan luri artinya melestarikan. Mereka meyakini bahwa dengan mengikuti jejak leluhur, tanpa menghilangkan setiap tahapannya akan memudahkan pengharapan mereka sampai kepada Sang Pencipta dan dikabulkan. Sikap tersebut menunjukkan kepatuhan masyarakat Tengger terhadap jejak para leluhur dalam menjalankan tradisinya.

Kepatuhan dalam tradisi jawa dikenal dengan istilah manut. Terminologi pada ilmu psikologi sosialistilah manut bisa dikaitkan dengan sikap obedience, yaitu sikap patuh seseorang terhadap orang lain yang memiliki kekuatan lebih (Milgran dalam Sarwono \& Meinarno, 2009). Baron dan Byrne (2005) dalam Adab dkk (2013:408) menyatakan bahwa sikap obedienceakan terwujud apabila seseorang dihadapkan pada sebuah otoritas yang mampu menjadikannaya sebagai model untuk dipatuhi. Otoritas dengan model yang baik akan mewujudkan suatu kepatuhan yang bernilai positif, sedangkan otoritas dengan model yang buruk akan menciptakan kepatuhan yang negatif. Sikap obedience pada konsep Titiluri, ditunjukkan dengan kepatuhan suatu masyarakat terhadap para leluhur dalam meneruskan agama, kepercayaan, dan adat istiadat yang dijadikannya sebagai model otoritas.

Otoritas pada konsep titiluri di kawasan Tengger tertuju pada leluhur, orang tua, orang yang dituakan atau dihormati, sehingga memiliki pengetahuan yang luas akan budaya dan dapat memberi teladan yang baik. Bentuk keteladanan dalam titiluri terdapat pada kepatuhan dalam tradisi, dimana tradisi Tengger yang sistematis dan berkala terus dijalankan tanpa absen untuk dirayakan. Masyarakat Tengger enggan meninggalkan kebaikan yang telah diajarkan oleh luluhur dalam perannya sebagai otoritas. Selain itu kegiatan sehari-hari turut dipengaruhi oleh keyakinan terhadap titiluri, sehingga membentuk kepribadian secara komunal. Hal tersebut sejalan dengan peran titiluri sebagai alat untuk konservasi budaya, dimana hal bak dijaga dan terus dilanjutkan guna menumbuhkan nilai luhur pada setiap masyarakat sampai kapanpun.

\section{Rumusan Masalah}

Sejalan dengan pemaparan latar belakang yang telah diuraikan, maka rumusan masalah dalam penelitian ini ialah:

1) Bagaimanakah titiluri bergerak sebagai bentuk aktualisasi tradisi masyarakat Tengger?

2) Bagaimanakah titiluri menjadi jati diri dari masyarakat Tengger?

3) Bagaimanakah peran titiluri dalam strategi konservasi budaya Tengger?

\section{TINJAUAN PUSTAKA}

\subsection{Tradisi Tengger}

Tradisi menurut Myror Wemwr dalam Arliman (2018:179) merupakan kepercayaan dan praktik yang diturunkan dari masa lalu, dimana saat menafsirkan 
kembali masa lalu dan dikomparasikan dengan saat ini, tradisi telah berubah. Tradisi dipertahankan bukan sekedar mengikuti apa yang telah dilakukan pada zaman dahulu, namun mempertahankan keluhuran nilai untuk menjaga norma yang diajaga. Sutarto dalam Febriani dkk (2018:784) mengungkapkan bahwa Tengger merupakan pusaka saujana (cultural landscape) eksistensinya akan memberi sumbangan yang lebih berarti yang apabila dibina dan dikelola dengan benar, untuk dirinya dan juga bagi Indonesia.

\subsection{Karakter Masyarakat Tengger}

Karakter dalam bahasa Indonesia ditujukan pada suatu tatanan sifat individu dan kolektif yang berbeda. Sedangkan karakter secara etimologis berarti suatu ciri moral atau mental secara keseluruhan atau sebagian pada suatu individu atau kelmpok individu berbeda dengan individu atau kelompok individu lainnya, atau ras suatu masyarakat (Hornby dkk dalam Effendi, 2015:177). Karakter terbentuk dari stimulus yang diberikan masyarakat hingga berpengaruh pada individu, dalam antropologi hal tersebut dengan kepribadian dasar (basic personality), begitu pula sebaliknya respon yang dimulai oleh individu yang kemudian saling mempengaruhi dan terbentuk kepribadian masyarakat secara umum (general personality). Proses saling mempengaruhi hingga kemudian menjadi ciri khas atau karakter pada masyarakat Tengger bersumber atau mengacu pada segala hal yang diturunkan dari leluhur (Sriwardhani, 2007).

\subsection{Konservasi Budaya}

Konservasi merupakan sebuah istilah yang akrab didengar dalam ranah lingkungan, bagaimana budaya dapat dipahami sebagai bentuk sebuah konservasi merupakan pembahasan yang diulas lebih dalam. Konservasi memiliki pengertian sebuah usaha dalam menjaga, melestarikan, serta menerima suatu pembangunan atau perubahan (Rahman, 2012). Perubahan yang dimaksud adalah perubahan secara alami yang terseleksi, bukan yang praktis dan terjadi secara serta-merta. Dalam konteks budaya, konservasi merupakan upaya mengelola perubahan menuju pelestarian nilai dan warisan budaya yang lebih baik dan berkesinambungan.

\section{METODE}

Penelitian ini menggunakan pendekatan kualitatif dengan desain atau model etnografi guna mendeskripsikan peran titiluri dalam menjaga dan mempertahankan kebudayaan masyarakat Tengger. Model etnografi berupaya mempelajari peristiwa kultural, yang menyajikan pandangan hidup subjek sebagai objek studi. Studi yang dimaksud berkaitan dengan bagaimana subjek berpikir, hidup, dan berperilaku (Endraswara, 2006:50). Model etnografi dipilih dalam penelitian kualitatif untuk menggambarkan secara detail wujud titiluri, yang sifatnya sebagai kepercayaan sekaligus karakter dari masyarakat Tengger sehingga mampu bergerak untuk melestarikan budaya. Budaya Tengger yang begitu banyak akhirnya terjamin keberlangsungannya.

Data penelitian berupa ekspresi folkloristik yang terwujud dalam ungkapan, tuturan, atau ekspresi lisan (oral), tindak/gerak atau perilaku simbolik yang mengandung falsafah titiluri. Data penelitian diperoleh dari sumber data, yaitu masyarakat Tengger, 
khususnya pelaku/penutur langsung, pegiat seni, atau pemangku tradisi, dalam hal ini dukun pandita, staf dukun pandita, kuncen, sesepuh desa, dan budayawan atau seniman, dan masyarakat kebanyakan. Secara spesifik lokus penelitan berada di Desa Tenggerwilayah di Kabupaten Pasuruan, Kecamatan Tosari.yakni desa Mororejo, Ngadiwono, Wanameta, dan Telagasari. Pemilihan beberapa lokasi dan narasumber dalam penelitian ini didasari atas pertimbangan pragmatis (bukan secara acak) yang mengaplikasikan titiluri pada kehidupan sehari-hari (bandingkan dengan Sudikan, 2001). Selanjutnya, data penelitian dikumpulkan dengan teknik wawancara tidak terstruktur dan observasi. Wawancara merupakan teknik pengumpulan data melalui komunikasi langsung antara peneliti terhadap responden yang dilakukan sesuai dengan tujuan penelitian secara sistematis (Arikonto, 2002:131 dalam Sultana \& Gunayasa, 2019:113). Wawancara dibersamai dengan observasi dalam teknik pengumpulan data untuk melakukan pengamatan secara langsung objek penelitian.

Data kemudian ditranskripsi dan dianalisis dalam tiga tahapan.Pertama, identifikasi data hasil wawancara dan pengamatan. Kedua, dilakukan klasifikasi data menjadi tiga hal yaitu, titiluri dalam konteks budaya, titiluri pada wujud karakteristik masyarakat Tengger, dan titiluri sebagai wujud penjagaan dan pelestarian. Ketiga, interpretasi terhadap data sehingga dapat dapat memberikan simpulan yang diyakini kebenarannya sesuai dengan apa yang terjadi dilapangan. Terakhir, pengujian validitas dan reliabilitas pada penelitian kualitatif disebut dengan pemeriksaan keabsahan data. Pada penelitian teknik yang digunakan adalah teknik triangulasi. Triangulasi berarti suatu teknik pemeriksaan keabsahan data yang dilakukan dengan cara memanfaatkan hal-hal (data) lain untuk pengecekan atau perbandingan data (Moleong, 2001:178). Data disahihkan melalui triangulasi teknik pengumpulan data, triangulasi sumber data, dan triangulasi teori.

\section{HASIL DAN PEMBAHASAN \\ 4.1 Titiluri Dalam Tradisi}

Secara bahasa, tradisi merupakan adat kebiasaan turun-temurun dari nenek moyang yang masih dijalankan dalam masyarakat.Pengertian tersebut menunjukkan bahwa tradisi secara bahasa sejalan dengan konsep titiluri pada masyarakat Tengger. Tradisi dapat terbentuk dengan berlangsungnya sebuah proses kegiatan yang terus menerus dilakukan, sesuatu dapat dilakukan dengan adanya acuan atau konsep dari leluhur sebagai pelaku pertama. Tengger yang memiliki ratusan tradisi, menghidupkan titiluri pada setiap sendi kegiatannya guna menjaga tradisi tersebut ada dan terus terpelihara. Upacara di Tengger merupakan salah satu tradisi yang terus dijaga dengan nilai luhur yang diyakini.

"Upacara dilakukan oleh masyarakat Tengger guna mendapat perlindungan dari segala macam bahaya. Upacara turut dilakukan sebagai bentuk penghormatan pada leluhur karena telah menurunkan serta mencontohkan hal-hal baik untuk di titiluri. Perwujudan rasa hormat ditunjukkan dengan adanya sesajen sebagai bentuk sesembahan."

(Pak Kariadi, wawancara2 Juni 2020)

Dapat dipahami bahwa upacara yang dilakukan oleh masyarakat Tengger lahir dan diteruskan untuk mewujudkan keselarasan dalam hidup. Keselarasan yang ingin 
diwujudkan adalah hidup tentrem ayem dalam bersosial, sehingga dalam upacara doa dipanjatkan guna dijauhkan hal-hal membahayakan serta agar dilindungi oleh para leluhur. Pada proses upacara terdapat ketentuan-ketentuan yang harus dipenuhi, sebagai perantara agar permohonan masyarakat dapat segera terwujud. Acara yang dilakukan oleh masyarakat Tengger memiliki tujuan dan terdapat nilai luhur. Acara tersebut dapat berupa ritual, kegiatan kebudayaan, kegiatan keagamaan, dan lainnya. Menyoroti titiluri pada setiap tradisi yang terdapat di Tengger, maka akan ditemukan satu konsep yang sama yaitu para leluhur sebagai otoritas dalam kepatuhan yang dilakukan oleh masyarakat.

\begin{abstract}
"Upacara yang berada di Tengger termasuk dalam titiluri, baik upacara yang dilakukan bersama-sama ataupun upacara secara individu atau perseorangan. Upacara yang sifatnya umum, mulai dari upacara pelaksanaanya setiap bulan, dalam setiap tahun empat kali, setiap tahun, lima tahun sekali disebut dengan titiluri. Upacara bari'an dilakukan setiap bulan guna menitiluri kegiatan yang dilakukan oleh leluhur jaman dahulu, sehingga wajib untuk dilakukan.Sehingga titiluri memiliki pengertian apa yang ada disuatu daerah dan wajib dilakukan."
\end{abstract}

(Romo Keto, wawancara 3 Juni 2020)

Berdasarkan pelaksananya, upacaradi Tengger terbagi atas upacara yang dilakukan secara bersama-sama atau berbentuk komunal serta upacara yang dilakukan oleh individu atau secara pribadi. Salah satu upacara yang dilakukan serentak atau bersama-sama ialah unan-unan yang dilakukan setiap lima tahun sekali. Unan-unan memiliki fungsi peran sebagai pengabsahan budaya serta sarana pendidikan (Sukmawan, 2020). Ritual ini merupakan bentuk kegiatan adat yang mengikuti ajaran leluhur guna menyempurnakan yang kurang supaya semesta berada dalam keseimbangan. Bentuk penghormatan pada leluhur disajikan secara variatif melalui aspek tahapan yang berurutan, penentuan tanggal pelaksaanaan, jenis dan kelengkapan sesaji, tempat pagelaran, ekspresi daras mantra, serta narasi verbal. Varian tersebut tentunya tidaklah sembarangan karena me-nitiluri adalah proses yang penuh kehatihatian.

Salah satu upacara yang sifatnya pribadi atau individu adalah slametan kelahiran. Otoritas tetua dalam kepatuhan tampak sebagaimana peran dukun alit pada slametan kelahiran di daerah Tengger. Slametan kelahiran diadakan oleh masyarakat Tengger guna menunjukkan syukur terhadap Tuhan Yang Maha Esa atas karunia telah diberikan anak. Ritual kelahiran yang dilakukan masyarakat Tengger mengandung nilai sosial yaitu hubungan manusia dengan manusia lainnya, nilai religius yang mengatur hubungan manusia terhadap Tuhan, serta pesan-pesan ekologis yaitu hubungan yang menunjukkan keselarasan manusia dengan alam semesta. Banyaknya nilai yang terkandung didalam ritual kelahiran menunjukkan bahwa terdapat kebaikan-kebaikan yang harus dijaga dan terus dipelihara oleh masyarakat Tengger. Oleh karena itu tradisi tersebut terus dilakukan secara turun-temurun, dari generasi ke generasi selanjutnya.

Bagi masyarakat pada umumnya, proses persalinan tidak bisa dilepaskan dari peran seorang bidan. Meskipun demikian, peran seorang dukun alit tidak dapat tergantikan. Masyarakat Tengger tetap memerlukan jasa dukun alit khususnya untuk perawatan pada masa pasca-melahirkan. Proses perawatan ibu dan jabang bayinya 
masih mengandalkan keterampilan dukun alit. Peran penting dukun alit tidak hanya sebagai sosok yang membantu ibu hamil untuk melahirkan dan perawatan sesudah melahirkan, tetapi juga sebagi pelaku utama ritual saat atau sesudah kelahiran, serta perantara menghaturkan sajian atau sesajen kepada para leluhur dan Sang Hyang Widhi. Proses melahirkan dapat dilakukan oleh seluruh tenaga medis yang memiliki pengalaman dan pendidikan mengenai persalinan, namun ritual berupa penghaturan sesajen serta proses lainnya tentu tidak dapat dilakukan oleh sembarangan orang. Oleh kerana itu peran dukun alit sebagai otoritas dalam tradisi ritual kelahiran guna menjaga titiluri pada masyarakat Tengger tidak dapat digantikan.

\subsection{Titiluri Sebagai Jati Diri Masyarakat}

Pada dasarnya budaya memiliki nilai-nilai yang senantiasa diwariskan, ditafsirkan dan dilaksanakan seiring dengan proses perubahan sosial kemasyarakatan. Pelaksanaan nilai-nilai budaya merupakan wujud eksistensi budaya yang diamalkan oleh masyarakat. Eksistensi budaya serta nilai-nilai luhur kebudayaan yang dimiliki Indonesia merupakan sarana dalam menanamkan karakter masyarakat, karakter pribadi atau yang bersifat privat maupun karakter terhadap publik. Geertz (1992:5) dalam Yunus (2013) menyebutkan bahwa kebudayaan adalah "pola dari pengertian-pengertian atau makna yang terjalin secara menyeluruh dalam simbol-simbol yang ditransmisikan secara historis, suatu sistem mengenai konsepsikonsepsi yang diwariskan dalam bentukbentuk simbolik yang dengan cara tersebut manusia berkomunikasi, melestarikan dan mengembangkan pengetahuan dan sikap mereka terhadap kehidupan.

Sikap terhadap kehidupan merupakan perwujudan dari karakter masyarakat dalam kesehariannya. Perwujudan titiluri dalam meneladani para leluhur di kawasan Tengger tidak berhenti pada ritual ataupun kegiatan semata, namun juga pembawaan masyarakatnya dalam kehidupan sehari-hari.

Bentuk titiluri hampir pada seluruh aspek kehidupan, termasuk karakter dan kebiasaan pada orang Tengger. Karakter orang Tengger ialah apa adanya, meskipun tidak semuanya namun sebagian besar masyarakat Tengger memilih hidup apa adanya dan lugu. Lainnya ialah kegiatan bercocok tanam, di Tengger jarang sekali pendidikan anakanaknya mengambil bidang pertanian namun hampir sebagian besar mengerti dan memahami cara bercocok tanam. Hal ini termasuk dalam titiluri.Titiluri ini sifatnya sambung-menyambung, dari buyut ke kakek, kakek ke bapak, bapak ke anak, dan seterusnya sehingga pelajaran dan ilmu itu sambung menyanggung.

(Romo Keto, wawancara 3 Juni 2020)

Karakter pribadi yang dicontohkan oleh para leluhur kemudian menjadi karakter pribadi pada masyarakat Tengger ialah sikap lugu, yang artinya jujur menjadi dasar dalam berperilaku. Sebuah perkataan yang diucapkan menunjukkan perilaku yang akan dilakukan secara benar tanpa ada perubahan meskipun akan mendapat pemakluman. Jujur merupakan sikap yang harus dimiliki oleh setiap orang guna menjadi pribadi yang baik.Sikap luhur tersebut haruslah diteruskan atau titiluri guna mewujudkan masyarakat dengan kepribadian yang baik. Maka peran titiluri disini tidak hanya mewarisi tradisi yang sifatnya proses kegiatan, namun juga proses panjang dalam hidup yaitu kepribadian baik yang turut serta diikuti. 
Sebagaimana dipahami bahwa sebagian besar masyarakat Tengger memiliki profesi sebagai petani. Marianno (1993) dalam Surtato (2006) mengungkapkan bahwa masyarakat Tengger yang tinggal secara berkelompok di bukit yang dekat deangan lahan pertaniannya merupakan petani tangguh.Tanahnya yang subur menjadikan Tengger sebagai kawasan dengan komoditi sayur unggul. Mata pencaharian masyarakatnya 95\% sebagai petani, sedangkan 5\% berprofesi sebagai pedagang, usaha jasa, pegawai negeri, dan buruh.Mata pencaharian merupakan bagian dari kehidupan manusia yang menyangkut keberlangsungan hidupnya, hal ini terjadi akibat kebutuhan jasmani yang harus dipenuhi menurut Ratna (2011:400) dalam Irawan dkk (2015:139). Tanah gembur serta mayoritas bercocok tanam membuat masyarakatnya mahir sehingga saling menurunkan kemampuan dari buyut ke kakek, kakek ke bapak, bapak ke anak, dan seterusnya.

Menariknya di Tenggerjika tanaman hasil panen ditumpuk di pinggir sawah atau lahan selama semalaman tidak akan hilang. Hal ini menunjukkan karakter jujur pada masyarakat Tengger sehingga tidak akan mengambil sesuatu yang bukan miliknya. Hal tersebut merupakan titiluri pada ranah sifat atau karakter. Watak seluruh masyarakat Tengger memang tidaklah sama persis, manusia bisa melakukan sesuatu yang buruk dengan mengikuti nafsu, namun dengan adanya titiluri pada masyarakat Tengger menjadi penjaga akan hal-hal buruk tersebut.

Cara berpakaian merupakan bagian dari titiluri, jika laki-laki menggunkan udeng bukanlah saat ini saja, namun sejak dahulu leluhur telah menggunakan udeng. Meskipun dalam penggunaannya tidak setiap hari namun pada setiap acara atau kegiatan di Tengger, dominan menggunakan udeng untuk laki-lakinya. Hal ini bukanlah karena suruhan atau perintah, didasari oleh perasaan dan kesadaran diri karena bagian dari titiluri yang harus diikuti. Apapun yang ada di Tengger merupakan bagian dari titiluri.

(Romo Keto, wawancara 3 Juni 2020)

Bagian dari titiluri lainnya ialah ciri khas dalam berpakaian. Udeng merupakan ikat kepala khas Tengger yang digunakan oleh laki-laki. Pada saat berlangsung upacara atau tradisi udeng digunakan oleh sebagian besar laki-laki Tengger, hampir tidak ada yang akan meninggalkannya. Ciri khas pakaian yang dikenakan perempuan Tengger adalah jarik. Sesuatu yang dikenakan oleh masyarakat Tengger dipengaruhi oleh bagaimana leluhur terdahulu dalam penggunaannya, oleh karena itu ciri khas berpakaian termasuk dalam sesuatu yang dititiluri.

\subsection{Peran Titiluri dalam Konservasi Budaya}

Konservasi pada konteks budaya meruapakan pengelolaan perubahan alami pada budaya dalam upaya pelestarian keluhuran yang telah diwariskan. Terdapat empat nilai yang terkandung dalam konsep konservasi, yaitu menanam, memanfaatkan, melestarikan dan mempelajari (Rahman, 2012). Secara filosofis dalam keterkaitannya dengan budaya, tentu keempat hal tersebut dapat dimaknai dengan hal yang lebih mendalam dibandingkan konservasi pada bidang lingkungan. Konservasi budaya dengan empat poin utamanya turut termuat dalam konsep titiluri, secara terperinci akan dijelaskan pada pengertian berikut. 
Pertama ialah menanamkan budaya.Menanam secara filosofis dapat dimaksudkan untuk meletakkan nilai-nilai fundamental dan luhur yang telah mengakar menjadi pedoman atau pandangan hidup dan dasar bagi sebuah bangsa (Rahman, 2012). Nilai-nilai luhur tersebut berawal dan berasal dari nilai-nilai luhur yang disepakati oleh rakyat penduduk wilayah tertentu, kemudian meluas dan disepakati oleh masyarakat dan bangsa. Dapat disimpulkan bahwa menanamkan budaya merupakan langkah awal dari lahirnya proses turun-temurun atau menurunkan budaya yang ada. Maka hal tersebut dapat juga disebut dengan mengajarkan suatu kepercayaan yang diyakini. Kegiatan belajar merupakan suatu proses yang tak boleh dihilangkan, karena dengan belajar suatu nilai luhur akan didapatkan sehingga pada proses selanjutnya tidak menemui kesesatan.

Pada saat upacara Karo yang merupakan hari raya bagi umat Hindu di Tengger, terdapat tari Sodoran sebagai pembuka. Tari Sodoran memiliki sejarah penciptaannya, yaitu nenek moyang bercerita menganai beberapa hal tabu yang ada dalam masyarakat. Penceritaan hal tabu bukanlah untuk mengumbar aib, namun sebagai pengingat pada generasi muda agar tidak terlena pada dunia yang fana atau sementara. Nilai pembelajaran seperti ini yang pada akhirnya menjadikan budaya patut untuk terus dilakukan, guna menamkan nilai luhur dari nenek moyang. Oleh karena itu tari Sodoran pada saat upacara Karo tidak mungkin ditinggalkan.

Keduaadalah pemanfaatan budaya.Nilai yang disemai akan tumbuh menjadi pedoman, petunjuk, dan aturan dalam bertutur kata, berperilaku, dan berbuat dalam hidup dan berhubungan satu sama lain. Pada proses memanfaatkan budaya dapat disebut juga dengan pengaplikasian budaya yang telah dipelajari oleh suatu masyarakat di dalam daerahnya. Bentuk pelaksanaanya dapat berupa sebuah tingkah laku, kegiatan keagamaan, dan lain sebagainya. Pada konsep titiluri yang telah menguat di Tengger ditunjukkan dengan karakter masyarakat yang lugu, jujur dan hidup apa adanya. Meskipun dalam pelaksanaannya tidak semua orang berbuat demikian, namun mayoritas karakter baik tersebut melekat pada masyarakat Tengger sebagai buah hasil dari me-nitiluriapa yang diajarkan oleh leluhur.

Ketiga adalah pelestarian budaya. Pelestarian sebagai kegiatan atau yang dilakukan secara terus menerus, terarah dan terpadu guna mewujudkan tujuan tertentu yang mencerminkan adanya sesuatu yang tetap dan abadi, bersifat dinamis, luwes, dan selektif (Nahak, 2019:71-72). Pelestarian budaya adalah upaya untuk mempertahankan nilai-nilai seni budaya, nilai tradisional dengan mengembangkan perwujudan yang bersifat dinamis, luwes dan selektif, serta menyesuaikan dengan situasi dan kondisi yang selalu berubah dan berkembang (Widjaja dalam Ranjabar, 2006:56).

"Dalam pelaksanaannya penuh kehati-hatian, karena jika tidak laksanakan ora ilok (tidak baik). Nenek moyang telah melakukan hal itu maka wajib dilakukan oleh cucu atau keturunannya, oleh karena itu titiluri dipegang teguh oleh masyarakat Tengger. Terdapat beberapa acara yang wajib dilaksanakan, semuanya terlaksana dengan baik sampai sekarang di Tengger. Titiluri ditanamkan guna menjaga budaya agar tetap eksis dan tidak ditinggalkan. Banyak budaya yang wajib dilakukan dan harus dilestarikan oleh masyarakat Tengger." 
Selaras dengan pengertian titilurisebagai 'meniti' dan 'melestarikan', maka peran kuat keberadaan titiluri di tengah-tengah masyarakat Tengger adalah melestarikan segala budaya yang ada. Nilai melestarikan ini diharapkan mampu menumbuhkan daya tahan budaya terhadap tekanan-tekanan modernisasi yang terjadi. Modernitas merupakan tuntutan jaman yang harus diikuti, namun nilai luhur yang disampaikan nenek moyang tentu tidak boleh ditinggalkan guna menjaga keseimbangan alam. Titiluri menjadi pawang atas hujaman modernitas yang berada di Tengger guna menjaga nilai baik yang telah tercipta sejak dahulu.

Terakhir ialah mempelajari budaya kembali.Belajar dengan mempelajari warisan budaya sebagai nilai keempat dari konservasi adalah langkah yang bijak dan teruji, sebab belajar berarti juga membaca fenomena dan berzikir tentang keagungan. Belajar dari menanam tanaman, menyemai nilai; belajar cara memanfaatkan tanaman dan warisan budaya; belajar cara melestarikan tanaman dan warisan budaya akan diperoleh bagaimana konservasi dilaksanakan secara utuh dan berkesimbangan (Rahman, 2012).

"Mengajarkan titiluri pada generasi selanjutnya melalui pemantapan oleh orang tua. Pemantapan disini dilakukan oleh orang tua sebagai pengingat agar terus melanjutkan berbagai titiluri. Secara umum seperti pembinaan yang sifatnya pengajaran justru di Tengger tidak ada. Orang tua masing-masing memberikan pengetahuan untuk melanjutkan budaya dan segala hal yang titiluri. Pembelajaran dari orang tua ke anak menjadi sarana menanamkan titiluri sehingga sedari kecil masyarakat telah meyakini titiluri itu sendiri yang kemudian dipegang teguh hingga besar. Keyakinan menjadi kunci dalam memegang erat kepercayaan."

(Romo Keto, wawancara 3 Juni 2020)

Peran keluarga, khususnya orang tua, dibutuhkan guna mengajarkan kepada anak serta keturunannya nanti atas kekayaan budaya serta tradisi yang ada. Masyarakat Tengger memahami poin tersebut dengan baik sehingga setiap orang tua dapat memberikan contoh kepada anaknya. Contoh dilakukan dengan menunjukkan bahwa mereka masih dan terus mengikuti tradisi yang ada. Pengajaran terbaik adalah dengan praktik secara langsung sehingga anak dapat memahami budaya secara konsisten atas apa yang dilakukan oleh orang tuanya. Begitulah cara titiluri dapat mengakar pada setiap individu masyarakat Tengger. Banyak fenomena alam dan kehidupan masa lalu yang tertulis dalam warisan budaya yang perlu menjadi pelajaran untuk menatap masa depan. Persoalannya, mampukah kita membuka rahasia tersebut untuk menjadi pertimbangan pemecahan lingkungan pada masa yang akan datang.

\section{SIMPULAN}

Titilurimenjiwai setiap sendi kehidupan masyarakat Tengger. Tidak hanya teraktualisasi dalam pelaksanaan berbagai upacara, titiluri juga hadir dalam bentuk jati diri masyarakat Tengger, dengan melekatnya karakter diri, pekerjaan, dan ciri khas berpakaian. Titiluri pada masyarakat Tengger menjadi sebuah prinsip yang dipegang teguh guna menjaga keberagaman budaya yang ada. Dengan mengikuti segala yang diajarkan oleh leluhur, kebajikan-kebajikan dialirkan secara tutun-temurun sehingga menjadi pegangan erat dalam menghadapi berbagai perubahan dalam tatanan kehidupan. Tengger saat ini telah dihuni pula oleh para pendatang, sehingga tidak 
sepenuhnya masyarakat Tengger asli. Masyarakat yang asli dari kawasan Tengger akan memegang teguh titiluri, karena jika tidak melaksanakannya mereka akan merasa takut. Meskipun telah berpindah keyakinan, titiluri tetap dilakukan dan tidak ditinggalkan. Masyarakat Tengger meyakini bahwa melakukan sesuatu yang tidak seharusnya akan mendatangkan rintangan-rintangan dalam hidup, baik permasalahan ekonomi, kesehatan, keselamatan maupunpermasalahan sosial. Oleh karena, titiluri wajib dilakukan dan dilestarikan. Keselarasan hidup diperjuangkan oleh masyarakat Tengger dengan memegang teguh titiluri dalam keseharian.

Titiluri memiliki peran mengonservasi budaya Tengger dan menjadi prinsip dalam mempertahankan keluhuran yang dibangun oleh nenek moyang. Terpaan kuat modernisasi adalah tempaan hebat bagi pendewasaan tradisi Tengger. Tempan kemajuan jaman ini tentu menguntungkan bagi ketahanan budaya tengger menuju konservasi budaya secara berkelanjutan.

\section{DAFTAR RUJUKAN}

Adab, Gugus dkk. 2013. Bahagiakah Kalau Manut: Studi Kepatuhan pada Masyarakat Jawa. Jurnal: Universitas Muhammadiyah Surakarta.

Arliman, Laurensius. 2018. Hukum Adat Di Indonesia Dalam Pandangan Para Ahli Dan Konsep Pemberlakuannya di Indonesia. Jurnal Selat. Vol. 5, No. 2, Halaman 178-190. https://doi.org/10.31629/selat.v5i2.320.

Effendi, Nursyiwarwan. 2015. Pemahaman dan pembentukan Karakter Masyarakat : Realitas dan Pandangan Antropologi. Tingkap: Jurnal Ilmiah Ilmu-Ilmu Sosial Budaya \& Ekonomi. 11(2), 175-185. DOI: - . http://ejournal.unp.ac.id/index.php/tingkap/article/view/6204/4820 .

Endraswara, Suwardi. 2006 Metodologi Penelitian Kebudayaan.Yogyakarta: Gadjah Mada University Press.

Febriani, R, P, Caesarilla Wahyu, dan Manda, MS. 2018. Slametan Tengger sebagai Mekanisme dalam Menjaga Tradisi dan Membangun Integrasi.Dalam Prosiding Industrial Research Workshop and National Seminar. 9, 784-789. DOI: https://doi.org/10.35313/irwns.v9i0.1150.

Irawan, Wawan; Mahyudi, Johan \& Sukri, Muhammad. 2018.Unsur-Unsur Kebudayaan dalam TeksNggahi Dana pada Masyarakat Dompu: Suatu Pendekatan Arketipel Pragmatik. Lingua, 15(2): 131-146.DOI: 10.30957/lingua.v15i2.484.

Moleong, L. R. 2010. Metode Penelitian Kualitatif. Bandung : Remaja Rosda Karya.

Nahak, Hildigardis M. I. 2019. Upaya Melestarikan Budaya Indonesia Di Era Globalisasi. Online. Jurnal Sosiologi Nusantara.5 (1), 195-176.DOI ://doi.org/10.33369/jsn.5.1.65-76.

Rachman, Maman. 2012. Konservasi Nilai dan Warisan Budaya.Indonesian Journal of $\begin{array}{llll}\text { Conservation. } & 1 & \text { (1), 30-39. } & \text { DOI }\end{array}$ https://journal.unnes.ac.id/nju/index.php/ijc/article/view/2062 .

Ranjabar. Jacobus, 2006, Sistem Sosial Budaya Indonesia, Suatu Pengatar, Bandung: Ghalia Indonesia.

Sarwono, S.W. dan Meinarno, E.A. 2009.Psikologi sosial. Jakarta: Salemba Humanika. 
Sriwardhani, T. 2007. Aspek Ritual Dan Maknanya Dalam Peringatan Kasada Pada Masyarakat Tengger Jawa Timur. Jurnal Daring. http://www.academia.edu/download/51504479/Makna_Upacra_Kasada.pdf.

Sudikan, Setya Yuwana. 2001. Metode Penelitian Kebudayaan. Surabaya: Citra wacana.

Sultana, Rusdiawan dan Gunayasa, Ida Bagus Kade. 2019. Fungsi Cerita Rakyatsabuk Bidadari dalam Masyarakat Suku Sasak.Lingua.16 (1), 109-112. DOI: 10.30957/lingua.v16i1.578.

Sukmawan, Sony dkk. 2020. Dimensi Ekologi Folklor Unan-Unan Tengger. Jurnal Ilmiah Edukasi \& Sosial. 11(1), 60-66. DOI: - . https://jiesjournal.com/index.php/jies/article/view/224.

Sutarto, Ayu. 2006. Sekilas Tentang Masyarakat Tengger. Makalah, Disajikan pada acara Pembekalan Jelajah Budaya 2006 yang diselenggarakan oleh Balai Kajian Sejarah dan Nilai Tradisional Yogyakarta, 2004.

Warsaa, Yogi Widya Saka. 2019. Visualisasi Upacara Tawur Agung Kesanga dalam Film Dokumenter "Di Balik Awan Tengger.Jurnal Penciptaan dan Pengkajian Seni. 4(1), 68-83. DOI: http://journal.isi.ac.id/index.php/invensi/article/view/2671 .

Yunus, Rasid. 2013. Transformasi Nilai-Nilai Budaya Lokal Sebagai Upaya Pembangunan Karakter Bangsa (Penelitian Studi Kasus Budaya Huyula Di Kota Gorontalo). Tesis: Universitas Pendidikan Indonesia. 
LINGUA, Vol. 17, No. 2, September 2020

p ISSN: 1979 9411; e -ISSN: 2442 238X

Website: soloclcs.org; Email: presslingua@gmail.com

Center of Language and Cultural Studies, Surakarta, Indonesia

Hasanah, Fitria, Dina \& Sukmawan, Sony. (2020). Titiluri Tegger: Aktualisasi Tradisi,

Refleksi Jari Diri dan Strategi Komunikasi.

Lingua (2020), 17(2): 157-168. DOI: 10.30957/lingua.v17i2.643. 